THE KURUME MEDICAL JOURNAL Vol. 17, No. 4, 1970

\title{
INHIBITORY ACTIVITY OF ABOB ON THE GROWTH OF INFLUENZA VIRUS A (Hong Kong)
}

\author{
MASAHISA SHINGU, YOSHIHIRO TANAKA, SHIGEYUKI NOMIYAMA \\ AND YOH NAKAGAWA \\ Department of Microbiology, Kurume University School of Medicine, \\ Kurume, Japan
}

(Received for publication August 29, 1970)

Many papers report $\left.{ }^{1)}-12\right)$ the inhibitory effect of $\mathrm{N}^{1}, \mathrm{~N}^{1}$-anhydrobis- $(\beta$ hydroxyethyl) biguanide hydrochloride (ABOB) on influenza virus multiplication and its prophylactic and therapeutic evaluation in clinical trials.

Inhibitory activity of $\mathrm{ABOB}$ on new type of influenza $\mathrm{A}$ virus (Aichi/2/68 strain), was tested in this study. This type of virus came into epidemic in Hong Kong in summer 1968. The antigenic properties of this virus were a little different from type A2 virus which is a previous epidemic strain.

\section{MATERIALS AND METHODS}

Virus: Influenza A virus (Aichi/2/68 strain)*, at its 8th egg passage, was used in this study. The strain was propagated in chorioallantoic cavity of 11 days-old egg.

Drug: $\mathrm{N}^{1}-\mathrm{N}^{1}=$ anhydrobis- $\left(\beta\right.$-hydroxyethyl) biguanide-HCl (ABOB) ${ }^{* *}$ was freely soluble in water and various concentrations of it in sterile physiologic saline were used throughout these experiments. As a rule, fresh solutions were prepared immediately before each administration.

Tissue culture: Primary monkey kidney cells, primary chick embryonal kidney cells and primary human embryonal lung cells were employed thoughout this study.

Method of culture and virus inoculation were previously described.

Infectivity titration: Specimens were made in serial tenfold dilution and $0.1 \mathrm{ml}$ of each dilution was inoculated into cell culure tube or chorioallantoic cavity of 11 days-old egg. Five culture tubes were used for each dilution.

Primary monkey kidney cell culture tube was considered to be infected when at least showed viral haemagglutinin in culture fluid 7 days after inocu-

* The strain was supplied by courtesy of Dr. M. Kaji, Kyushu University, Fukuoka.

** ABOB was kindly supplied from the Sumitomo Chemical CO. Osaka. 
lation. Primary chick embryonal kidney cell culture tube was considered to be infected when at least 20 per cent of the cells showed viral cytopathic effect 5 days after inoculation. Primary human embryonal lung cells culture tube was considered to be infected when at least showed haemadsorption phenomenon 5 days after inoculation. The 50 per cent endpoint was calculated by the Reed and Muench's Method ${ }^{13)}$.

Test for antiviral activity in ovo : Eleven-day old embryonated eggs were treated with $0.1 \mathrm{ml}$ of $\mathrm{ABOB}$ solution at a desired concentration via the allantoic route immediately following the inoculation of $0.1 \mathrm{ml}$ of tenfold diluted solution $\left(10^{3}, 10^{4}, 10^{5}, 10^{6}\right.$ and $\left.10^{7}\right)$ of the Hong Kong strain of influenza type A virus. The eggs were incubated at $34^{\circ} \mathrm{C}$ for 48 hours.

Test for antiviral activity in tissue culture: Tissue culture tubes were treated with $0.1 \mathrm{ml}$ of $\mathrm{ABOB}$ solution at a desired concentration immediately following the inoculation of $0.1 \mathrm{ml}$ of tenfold diluted solution of the Hong Kong strain of influenza type A virus. The tissue culture tubes were incubated at $35^{\circ} \mathrm{C}$ for 5 or 7 days.

\section{EXPERIMENTAL RESULTS}

Activity on Aichi/2/68 virus in primary cultured cells of monkey kidney (Cynomolgus irus);

The results are summarized in Table 1 . At the inoculum below 30 TCD 50, $0.1 \mathrm{mg} / \mathrm{ml}$ of $\mathrm{ABOB}$ completely inhibited the infection to the cells. When the cells were challenged with 100-300 TCD50 of virus, ABOB could not comletely inhibit the infection but could reduce the growth of virus.

TABLE 1

Activity of $A B O B$ on the growth of virus in primary monkey kidney cells

\begin{tabular}{c|c|c|c}
\hline Experiment & $\begin{array}{c}\text { ABOB treated } \\
(0.1 \mathrm{mg} / \mathrm{ml})\end{array}$ & Control & Log. difference \\
\hline 1 & $4.3^{*}$ & 5.7 & -1.4 \\
2 & 4.3 & 5.9 & -1.6 \\
3 & 4.7 & 5.9 & -1.2 \\
\hline
\end{tabular}

* Virus titer $\log 10$ TCD50/0.1 ml

Virus and $A B O B$ were added simultaneously

Activity in chorioallantoic cavity of 11 days-old egg;

The results are summarized in Table 2. Although ABOB (50 mg/egg) reduced a little the growth of the virus in the cavity from $10^{6.5}$ to $10^{5.9} / 0.1 \mathrm{ml}$. The compound failed to show significant effects even at the dose of $50 \mathrm{mg} / \mathrm{egg}$. 
TABLE 2

Acivivity of $A B O B$ on the growth of virus in chorioallantoic cavity of 11 days-old egg

\begin{tabular}{c|c|c|c}
\hline $\begin{array}{c}\text { ABOB Dose } \\
(\mathrm{mg} / \mathrm{egg})\end{array}$ & ABOB treated & Control & Log. difference \\
\hline 50 & 5.9 & 6.5 & -0.6 \\
10 & 6.1 & 6.5 & -0.4 \\
$?$ & 6.3 & 6.5 & -0.2 \\
\hline
\end{tabular}

* Virus titer $\log 10$ EID50/0.1 ml

Virus and $A B O B$ were added simultaneously

TABLF 3

Activity of $A B O B$ on the growth of the virus in primary chick embryonal kidney cells

\begin{tabular}{c|c|c|c}
\hline $\begin{array}{c}\text { ABOB Dose } \\
(\mathrm{mg} / \mathrm{ml})\end{array}$ & ABOB treated & Control & Log. difference \\
\hline 10 & toxic & - & - \\
1 & toxic & - & - \\
0.1 & $1.9^{*}$ & 5.7 & -3.8 \\
0.01 & 2.3 & 5.7 & -3.4 \\
0.001 & 4.5 & 5.7 & -1.2 \\
\hline
\end{tabular}

* Virus titer $\log 10$ TCD50/0.1 ml

$V$ irus and $A B O B$ were added simultaneously

TABLE 4

Activity of $A B O B$ on the growth of the virus in primary human embryonal lung cells

\begin{tabular}{c|c|c|c}
\hline $\begin{array}{c}\text { ABOB dose } \\
(\mathrm{mg} / \mathrm{ml})\end{array}$ & ABOB treated & Control & Log. difference \\
\hline 10 & toxic & - & - \\
1 & $3.7^{*}$ & 7.2 & -3.5 \\
0.1 & 4.5 & 7.2 & -2.7 \\
0.01 & 6.7 & 7.2 & -0.5 \\
0.001 & 7.1 & 7.2 & -0.1 \\
\hline
\end{tabular}

* Virus titer $\log 10$ TCD50/0.1 ml

Virus and $A B O B$ were added simultaneously

Activity in primary cultured cells of chick embryonal kidney from 18 days-old egg;

The results are summarized in Table 3. By $0.1 \mathrm{mg} / \mathrm{ml}$ of $\mathrm{ABOB}$ virus titer was reduced at the difference of $10^{3.8}$ from control and even at $0.01 \mathrm{mg} / \mathrm{ml}$ titer was reduced at $10^{3.4}$. 


\section{Activity in primary cultured cells of human embryonal lung;}

The results are summarized in Table 4. The virus titer was reduced $10^{2.7}$ and $10^{3.5}$ compared with control respectively treated with 0.1 and $1 \mathrm{mg} / \mathrm{ml}$ of the drug.

In these data $\mathrm{ABOB}$ inhibited much effectively the growth of new type of influenza in primary cultured-monkey kidney, -embryonal chick kidney and -human embryonal lung cells but slightly in chorioallantoic cavity of 11 daysold egg. As above mentioned, $A B O B$ was shown to have the inhibitory effect on the growth of this new type of influenza virus. It can be concluded that ABOB will be useful on chemoprophylaxis or chemotherapy of influeza Hong Kong virus that the pandemy was anticipated this winter.

TABLE 5

Summary of the inhibitory activity of $A B O B$ in various host cells

\begin{tabular}{l|c|c|c|c}
\hline \multirow{2}{*}{$\begin{array}{c}\mathrm{ABOB} \text { dose } \\
(\mathrm{mg} / \mathrm{ml})\end{array}$} & \multicolumn{4}{|c}{ logarismic difference of virus titer } \\
\cline { 2 - 5 } & Monkey kidney & $\begin{array}{c}\text { Chorioallantoic } \\
\text { cavity }\end{array}$ & Chick kidney & Human lung \\
\hline 1 & & -0.6 & & -3.5 \\
0.2 & -1.4 & -0.4 & -3.8 & -2.7 \\
0.1 & & & & \\
0.04 & & -0.2 & -3.4 & -0.5 \\
0.01 & & & -1.2 & -0.1 \\
0.001 & & & & \\
\hline
\end{tabular}

\section{DISCUSSION}

The study was carried out to know whether $A B O B$ can inhibit the Hong Kong strain of influenza A virus multiplication or not.

Those culture cells were treated with various concentrations of ABOB which were added to culture media and its viability was examined for 12 days after the treatment primary monkey cell could be used under the concentration of $0.1 \mathrm{mg} / \mathrm{ml}$ and primary embryonal chick kidney cell could be used under the concentration of $0.1 \mathrm{mg} / \mathrm{ml}$ and primary human embryonal lung cells could be used under the concentration of $1 \mathrm{mg} / \mathrm{ml}$ of $\mathrm{ABOB}$ for this experiment.

Tissue culture (primary monkey kidney cell, primary embryonal chick kidney cell and primary human embryonal lung cells) could be used under the concentration of $1 \mathrm{mg} / \mathrm{ml}$ or less of $\mathrm{ABOB}$ for this experiments.

The results obtained suggest that influenza virus multiplication in tissue culture cell was inhibited by the treatment of ABOB with the concentration of 1 or $0.1 \mathrm{mg} / \mathrm{ml}$ to the culture media, but slightly in chorioallantoic cavity of 11 days-old egg. 
As is known, the tissue culture consists of only one layers of cells, whereas the whole egg consists of a complete set of cells of an embryo.

\section{SUMMARY}

This paper reports the effect of $A B O B$ against Hong Kong strain of influenza A virus multiplication in primary monkey kidney cell, primary embryonal chick kidney cell and primary human embryonal lung cells.

The results obtained suggest that Hong Kong strain of influenza A virus multiplication in tissue culture cells was inhibited by the treatment of ABOB with the concentration of $0.1 \mathrm{mg} / \mathrm{ml}$ to the culture media, although no direct virucidal effects were demonstrated in vitro.

In general, the earlier beginning of $\mathrm{ABOB}$ treatment tended to bring the stronger inhibition of Hong Kong strain of influenza A virus multiplication.

\section{REFERENCES}

1) Melander, B. : $\mathrm{N}^{1}, \mathrm{~N}^{1}$-anhydrobis-( $\beta$-hydroxyethyl) biguanide-HCl (ABOB) in prophylaxis and suppression of experimental influenza. Antibiot. and Chemother., 10. 34-45, 1960.

2 ) Rhodes, R. E. and Herlocher, M. L. : Conference on ABOB and Flumidin, Stockholm, 1960.

3 ) IsHIDA, N., et al. : The effect of certain biguanide derivatives on the multiplication of myxoviruses in tissue culture. J. Antibiot., 15. 242-246, 1962.

4) Melander, B. : Correlation between antiviral activity in experimental animals and man. 2 nd International symposium of chemotherapy. Naples, 14-17, Sep., 1961.

5 ) Pilcher, K. S., Solke K. F. and Trosper, F. : Studies of chemical inhibitors of influenza virus multiplication. I. Biguanides and related compounds. Antibiotics and Chemother, 11, 381-389, 1961.

6) GARD, S. : "Conference on ABOB and Flumidin". Stockholm, Sweden, Oct., 28, 1960.

7 ) Ishida, $\mathrm{N}$, et al. : The effect of $\mathrm{N}^{1}, \mathrm{~N}^{1}$-anhydrobis- ( $\beta$ - hydroxyethyl) biguanide hydrochloride against the growth of Sendai virus in HeLa cell cultures. J. Antibiot., 15, 168-173, 1962.

8) Hesse, E. and Taubmann, G. : Die Wirkung des Biguanids und seine Derivate auf den Zuckerstoffwechsel. Arch. exp. Path. Pharmak., 142, 290-308, 1929.

9) Shapino, S. L., Parrio, V. A. and Freedman, L. : Hypoglycemic agents, 111. $\mathrm{N}^{1}$-alkyl and aralkylbiguanides. J. Amer. chem. Soc., 81, 3728-3736, 1956.

10) Liu, O. C. and Engle, C. G. : Conference on ABOB and Flumidin, Stockholm, 1960.

11) Glasky, A. J. and Holper, J. C. : Antimicrobial Agent and Chemotherapy, 688, 1963.

12) KAJI, M., et al. : Effect of $\mathrm{N}^{1}, \mathrm{~N}^{1}$-anhydrobis (-hydroxyethyl) biguanide hydrochloride (ABOB) against adenovirus. Chemotherapy, 14, 66, 1966.

13) Reed, J. L. and Muench, H. : A simple method of estimating fifty per cent endpoints. Amer. J. Hyg., 27. 493, 1938. 